\title{
Influences of Atmospheric Conditions and Air Mass on the Ratio of Ultraviolet to Total Solar Radiation
}

\author{
C. J. Riordan \\ R. L. Hulstrom \\ D. R. Myers
}

August 1990

Prepared under task number ST011253

Solar Energy Research Institute

A Division of Midwest Research institute

$16 i 7$ Cole Boulevard

Golden, Colorado 80401-3393

Prepared for the

U.S. Department of Energy

Contract No. DE-AC02-83CH10093 


\section{NOTICE}

This report was prepared as an account of work sponsored by an agency of the United States government. Neither the United States government nor any agency thereof, nor any of their employees, makes any warranty, express or implied, or assumes any legal liability or responsibility for the accuracy, completeness, or usefulness of any information, apparatus, product, or process disclosed, or represents that its use would not infringe privately owned rights. Reference herein to any specific commercial product, process, or service by trade name, trademark, manufacturer, or otherwise does not necessarily constitute or imply its endorsement, recommendation, or favoring by the United States government or any agency thereof. The views and opinions of authors expressed herein do not necessarily state or reflect those of the United States government or any agency thereof.

Printed in the United States of America

Available from:

National Technical Information Service

U.S. Department of Commerce

5285 Port Royal Road

Springfield, VA 22161

Price: Microfiche A01

Printed Copy $\mathrm{AO}$

Codes are used for pricing all publications. The code is determined by the number of pages in the publication. Information pertaining to the pricing codes can be found in the current issue of the following publications which are generally available in most libraries: Energy Research Abstracts (ERA); Government Reports Announcements and Index (GRA and I); Scientific and Technical Abstract Reports (STAR); and publication NTIS-PR-360 available from NTIS at the above address. 


\section{PREFACE}

This report was prepared for the Department of Energy/Solar Energy Research Institute (SERI) Solar Thermal Technology Program by the SERI Solar Radiation Research and Metrology Branch under the ultraviolet (UV) solar radiation resource modeling element of task number ST011253. It was prepared in response to the program's need to obtain preliminary estimates of UV solar radiation resources in the United States to establish the viability of technologies to detoxify hazardous wastes using UV solar radiation.

\section{ACKNOWLEDGMENTS}

SERI would like to acknowledge Dave Menicucci at the Sandia National Laboratories, Albuquerque, and Frank Vignola at the University of Oregon for their very helpful review of this report.

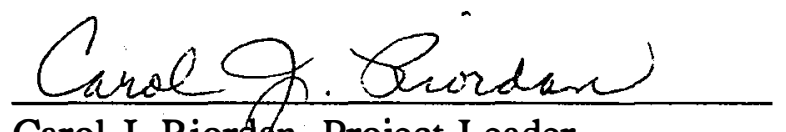

Carol J. Riordan, Project Leader

Solar Radiation Resource Assessment Project

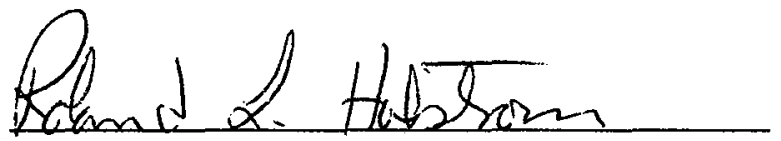

Roland L. Hulstrom

Solar Radiation Research and Metrology Branch

Approved for

SOLAR ENERGY RESEARCH INSTITUTE

Jack L. Stone, Director

Solar Electric Research Division 


\section{TABLE OF CONTENTS}

Page

Introduction $\ldots \ldots \ldots \ldots \ldots \ldots \ldots \ldots \ldots \ldots \ldots \ldots \ldots \ldots \ldots \ldots \ldots \ldots \ldots \ldots$

Atmospheric Effects on UV Solar Radiation $\ldots \ldots \ldots \ldots \ldots \ldots \ldots \ldots \ldots . \ldots . \ldots$.

Ratios of UV-to-Total Solar Radiation $\ldots \ldots \ldots \ldots \ldots \ldots \ldots \ldots \ldots \ldots \ldots$

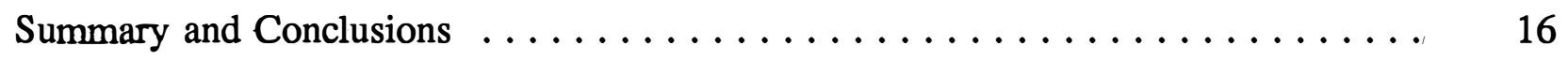

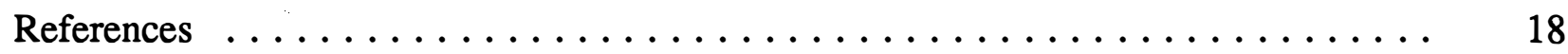




\section{LIST OF FIGURES}

$\underline{\text { Page }}$

Figure 1. Extraterrestrial spectral solar radiation plotted from 0.2 to $3.0 \mu \mathrm{m}[1] \ldots 2$

Figure 2. Air mass and solar components $\ldots \ldots \ldots \ldots \ldots \ldots \ldots \ldots \ldots$

Figure 3. Relative transmittance for different atmospheric constituents, calculated with the Air Force Geophysics Laboratory LOWTRAN-7 Direct-Normal Atmospheric Transmittance Code (midlatitude summer atmospheric model, rural aerosol profile, $40^{\circ}$ zenith angle) $\ldots \ldots \ldots \ldots \ldots \ldots$

Figure 4. Ratio of 5-minute values of UV global horizontal to total global horizontal solar radiation versus $\mathrm{K}_{\mathrm{t}}$ (measured at the SERI Solar Radiation Research Laboratory, January through December 1989) . . . .

Figure 5. Instantaneous direct-normal UV spectral solar radiation measurements and supporting data acquired at SERI in January and April 1990 (upper graph); spectral measurement uncertainty (lower graph) where CAL indicates calibration error sources and SR indicates spectroradiometer

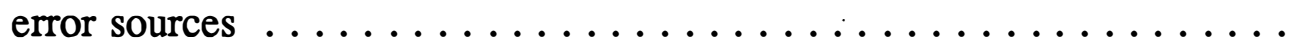

Figure 6. Ratio of integrated UV (300-400 nm) global horizontal solar radiation (measured with a LI-COR model LI-1800 spectroradiometer at 2-nm steps) to total global horizontal solar radiation measured with a PSP

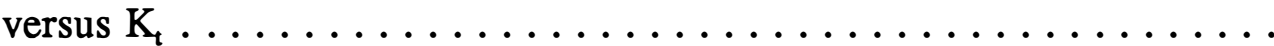

Figure 7. Ratio of integrated UV (300-400 $\mathrm{nm})$ direct-normal solar radiation to total direct-normal solar radiation measured with an NIP. The top and bottom curves are quadratic curve fits to the ratios based on data measured with the ISA UV spectroradiometer integrated between 280 and $400 \mathrm{~nm}$ (top) and between 280 and $385 \mathrm{~nm}$ (bottom). The middle curve is a quadratic curve fit to data measured with a LI-COR model LI-1800 spectroradiometer and integrated between 300 and $400 \mathrm{~nm} . \ldots \ldots \ldots \ldots \ldots$ 


\section{LIST OF TABLES}

$\underline{\text { Page }}$

Table 1. UV Percentage of Monthly Mean Total Global Solar Radiation on a Horizontal Surface at Dhahran, Saudi Arabia [6] ............

Table 2. UV Percentage of Monthly Mean Total Global Solar Radiation on a

Horizontal Surface at the Kuwait Institute for Scientific Research [7] . . .

Table 3. Mean Daily UV Percentage of Total Global Solar Radiation on a Horizontal Surface at Corvallis, Ore. $[8] \ldots \ldots \ldots \ldots \ldots \ldots \ldots$

Table 4. UV Percentage of Total Global Solar Radiation on a Horizontal Surface (Computed Three Different Ways) Cited in Reference Number $10 \ldots$. .

Table 5. Some Characteristics of the ISA/DH10 Spectroradiometer ..........

Table 6. UV Percentage of Total Direct Normal Solar Radiation for Instantaneous

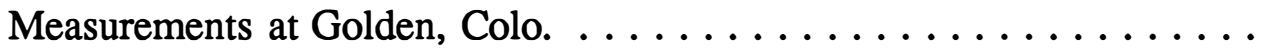




\section{INTRODUCTION}

The technology to detoxify hazardous wastes using ultraviolet (UV)* solar radiation is being investigated by the DOE/SERI Solar Thermal Technology Program. One of the elements of the technology evaluation is the assessment and characterization of UV solar radiation resources available for detoxification processes. Initially, simple methods are needed to establish preliminary estimates of UV solar radiation resources in the United States to evaluate the viability of this technology (for example, process rates). This report summarizes work performed for the Solar Thermal Technology Program by the Solar Radiation Research and Metrology Branch under the UV modeling element of task number ST011253, to assist the program with efforts to make preliminary estimates of UV resources by simply using a percentage of the total incoming solar radiation. Actual UV solar radiation measurements, including the spectral information needed to evaluate processes that use catalysts operating at specific wavelengths, are being addressed under other task elements.

This report describes the major atmospheric variables that determine the amount of UV solar radiation at the earth's surface, and how the ratio of UV-to-total solar radiation varies with atmospheric conditions. These ratios are calculated from broadband and spectral solar radiation measurements acquired at SERI, and obtained from the literature on modeled and measured UV solar radiation. The following sections discuss the atmospheric effects on UV solar radiation and provide UV-to-total solar radiation ratios from published studies, as well as measured values from SERI's data. A summary and conclusions are also given.

*UV solar radiation is defined for three regions of the spectrum:

UVA 320 to 400 nanometers $(\mathrm{nm})$

UVB 280 to $320 \mathrm{~nm}$

$\mathrm{UVC}<280 \mathrm{~nm}$

Total, or broadband, solar radiation refers to the region from 280 to $4000 \mathrm{~nm}$. However, it is important to note in this report that UV and broadband measurements are obtained using instruments that have specific wavelength responses. The differences in the response regions these instruments, as well as measurement uncertainty, contribute to the variability in reported $\mathrm{UV}$ and broadband solar radiation data. 


\section{ATMOSPHERIC EFFECTS ON UV SOLAR RADIATION}

This section gives a brief overview of major atmospheric variables that affect the amount and spectral distribution of UV solar radiation. It also defines variables that are used later in the report such as air mass and a cloudiness/clearness index called $\mathrm{K}_{\mathrm{r}}$.

The spectral (wavelength) distribution of solar radiation received at the top of the atmosphere is shown in Figure 1 [1]. When this radiation enters the atmosphere, it is absorbed and scattered by atmospheric constituents, such as air molecules, aerosols, water vapor, liquid water droplets, and clouds. Solar radiation that reaches the earth's surface directly from the sun's disk (not scattered or absorbed) is called direct-beam solar radiation, and that which has been scattered out of the direct-beam is called diffuse solar radiation (Figure 2). The sum of the direct radiation and diffuse radiation is called total or global solar radiation.

Air mass (Figure 2) refers to the relative path length of the direct solar beam through the atmosphere. It is approximately equal to the secant of the solar zenith angle for angles less than $60^{\circ}$; for example, air mass is 1.0 when the sun is directly overhead (zenith), 1.5 when the sun is at $48.2^{\circ}$, and 2.0 when the sun is at $60^{\circ}$. A simple expression for air mass is given by Kasten [2] for all solar zenith angles. As air mass increases, the direct beam traverses longer path lengths in the atmosphere, which results in more scattering and absorption of the direct beam and a lower

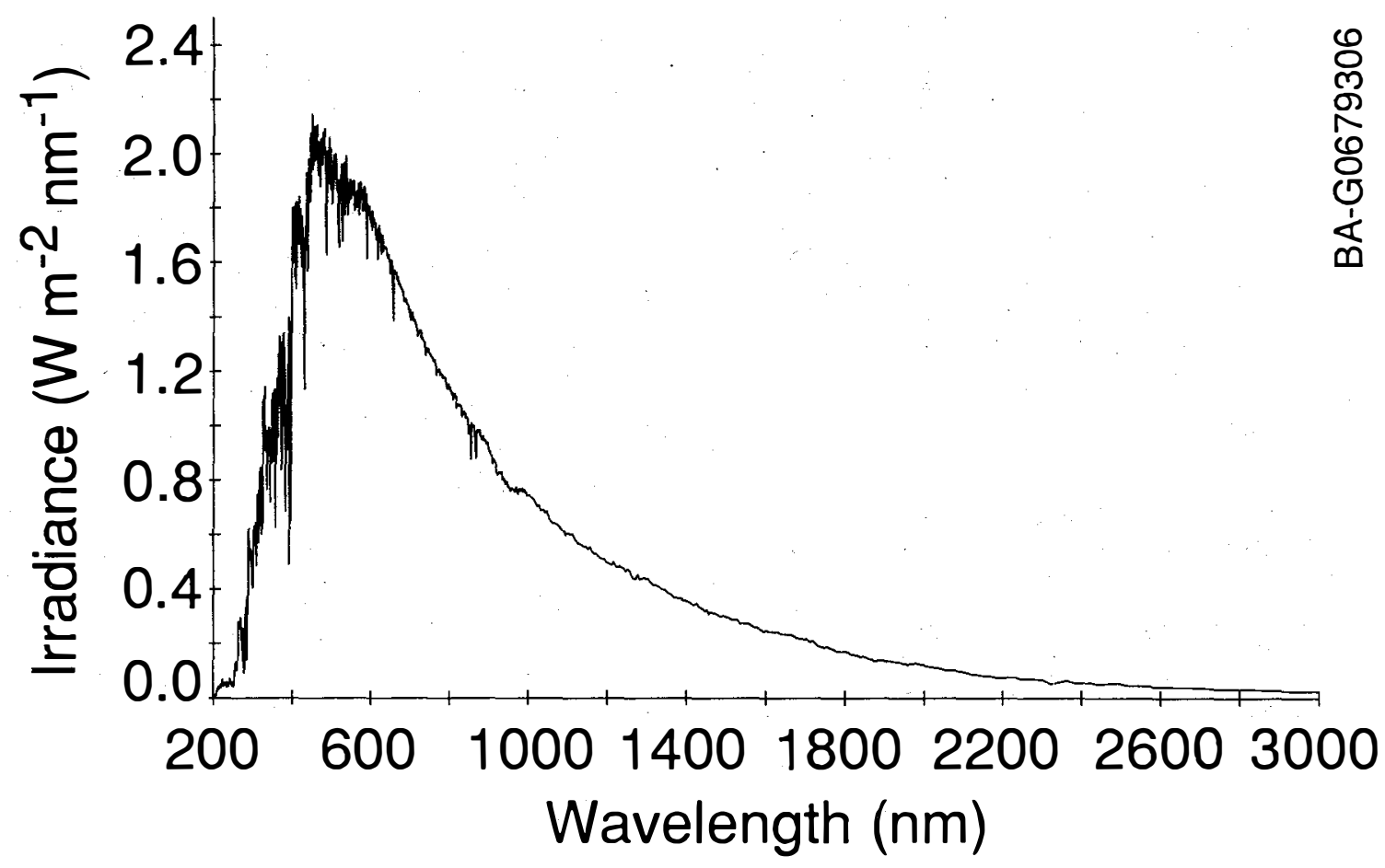

Figure 1. Extraterrestrial spectral solar radiation plotted from 0.2 to $3.0 \mu \mathrm{m}$ [1] 


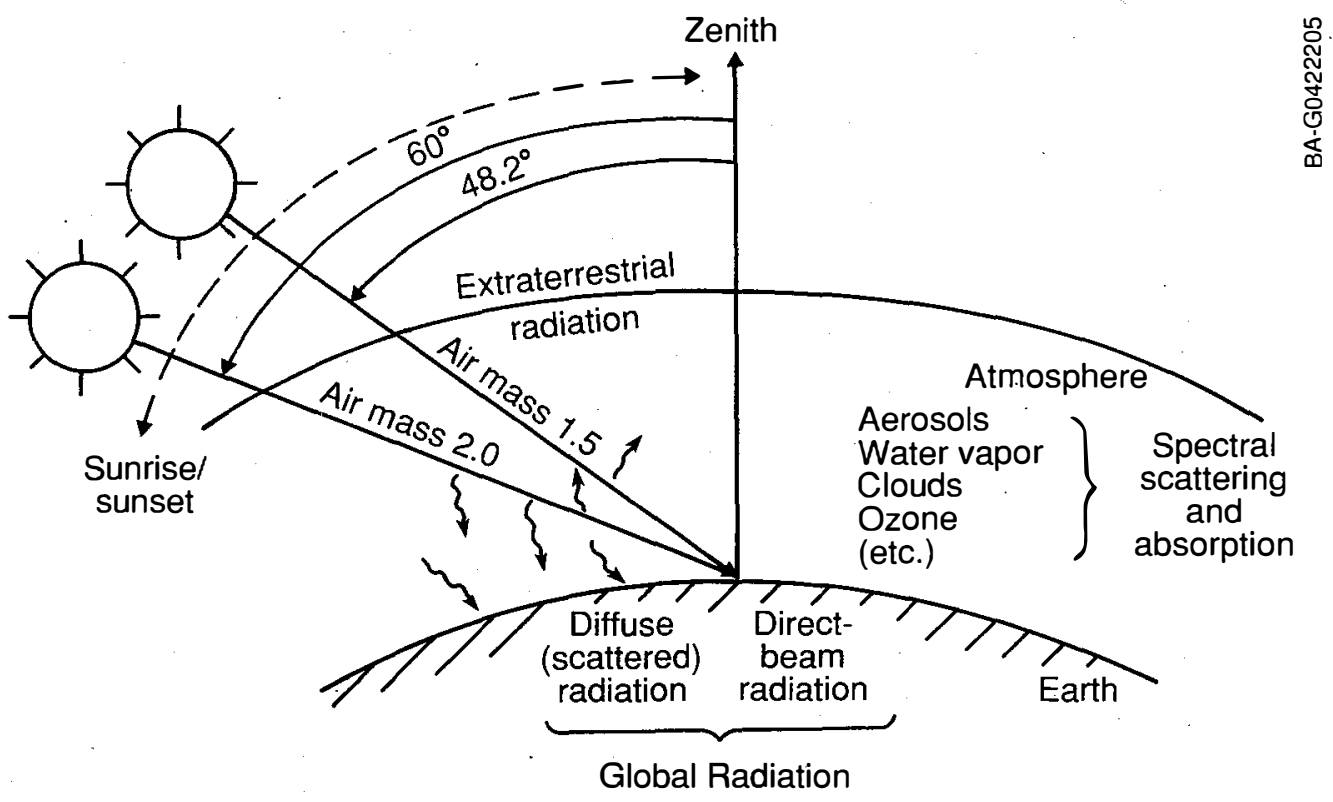

Figure 2. Air mass and solar components

percentage of direct-to-total solar radiation (for the same atmospheric conditions). There is also proportionally more scattering in the shorter wavelengths (UV and visible) compared to longer wavelengths because of the strong wavelength dependence of molecular and aerosol scattering. As will be shown later, this results in a more rapid decrease in the UV and visible wavelengths of the direct beam with increasing air mass values, and a shift in the spectrum toward longer wavelengths.

Solar radiation incident on a collector surface is equal to the direct beam multiplied by the cosine of the incidence angle, plus diffuse solar radiation from the sky and ground-reflected radiation in the collector's field of view. A simple equation is:

where

$$
I_{g}=I_{d n} x \cos \text { (incidence angle) }+I_{d}\left(\text { sky) }+I_{g r}\right. \text { (ground) }
$$

$\mathrm{I}_{\mathrm{g}}=$ total (global) solar radiation on a flat surface

$\mathrm{I}_{\mathrm{dn}}=$ direct-beam solar radiation, normal to the sun (direct normal)

$I_{d}=$ diffuse solar radiation

$\mathrm{I}_{\mathrm{gr}}=$ ground-reflected radiation 
If the collector is sun-tracking, the direct beam incidence angle is zero and if the collector is horizontal, the incidence angle is equal to the solar zenith angle. For other orientations of the collector, the incidence angle is a function of the azimuth and tilt of the collector and the azimuth and elevation of the sun. Concentrating or focusing collectors use the direct-beam component plus forward-scattered radiation around the sun's disk, called circumsolar radiation. The solar component used by each type of collector is important because the amount and spectral distributions of direct and diffuse solar radiation are different.

A general expression for transmittance $(\mathrm{T})$ of direct-beam solar radiation under cloudless skies at a specific wavelength $(\lambda)$ is [3]:

$$
T_{\lambda}=T_{r \lambda} \times T_{a \lambda} \times T_{o \lambda} \times T_{g \lambda} \times T_{w \lambda}
$$

where

$$
\begin{aligned}
& \mathrm{T}_{\mathrm{r} \lambda}=\text { the spectral transmittance due to molecular (Rayleigh) scattering } \\
& \mathrm{T}_{\mathrm{a} \lambda}=\text { the spectral transmittance due to scattering and absorption by aerosols } \\
& \mathrm{T}_{\mathrm{o} \lambda}=\text { the spectral transmittance due to absorption by the atmospheric ozone layer } \\
& \mathrm{T}_{\mathrm{g} \lambda}=\text { the spectral transmittance due to absorption by uniformly mixed gases, such as } \\
& \quad \text { carbon dioxide and oxygen } \\
& \mathrm{T}_{\mathrm{w} \lambda}=\text { the spectral transmittance due to absorption by water vapor }
\end{aligned}
$$

The major cloudless-sky attenuation processes in the UV region of the spectrum are molecular (Rayleigh) scattering, aerosol scattering and absorption, and ozone absorption. Various expressions have been derived to calculate transmittance due to these processes. Examples [3] are:

Rayleigh scattering

$$
\mathrm{T}_{\mathrm{r \lambda}}=\operatorname{Exp}\left[-0.008735\left(\lambda^{-4.08}\right) \mathrm{M}^{\prime}\right]
$$

where

$\mathrm{M}^{\prime}=$ air mass values that have been pressure corrected to account for the decreased density of air molecules at different elevations

Aerosol scattering and absorption

$$
\mathrm{T}_{\alpha \lambda}=\operatorname{Exp}\left(-\beta \lambda^{-\alpha} \mathrm{M}\right)
$$


where

$\beta=$ the turbidity coefficient

$\alpha=$ the wavelength exponent

$\mathrm{M}=$ air mass

Ozone absorption

$$
\mathrm{T}_{\mathrm{o} \lambda}=\operatorname{Exp}\left(-\mathrm{k}_{\mathrm{o} \lambda} 1 \mathrm{M}\right)
$$

where

$$
\begin{aligned}
& \mathrm{k}_{\mathrm{o} \lambda}=\text { the spectral absorption coefficient } \ddot{\mathrm{Y}} \\
& 1=\text { ozone amount }
\end{aligned}
$$

An example of the relative transmittance for these three processes (and others) is shown in Figure 3. Ozone absorption can be considered relatively constant in the UV region because it

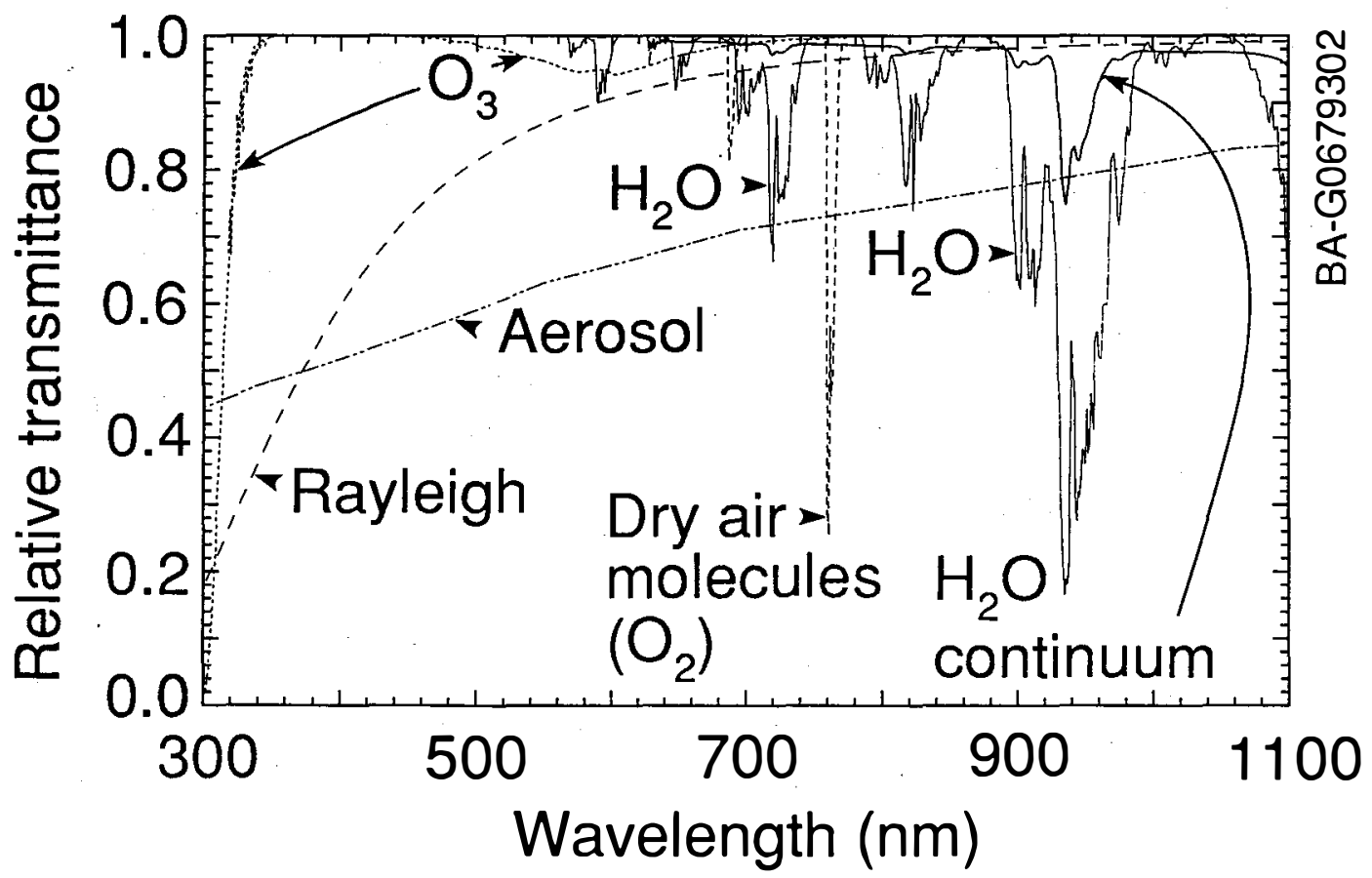

Figure 3. Relative transmittance for different atmospheric constituents, calculated with the Air Force Geophysics Laboratory LOWTRAN-7 Direct-Normạl Atmospheric Transmittance Code (midlatitude summer atmospheric model, rural aerosol profile, $40^{\circ}$ zenith angle) 
is a strong absorber in the Hartley (200 to $300 \mathrm{~nm}$ ) and Huggins (300 to $360 \mathrm{~nm}$ ) bands. Rayleigh scattering can be considered constant for a given altitude; it is a strong function of wavelength (inverse fourth power) and $\mathbf{M}^{\prime}$. Rayleigh scattering decreases with increasing elevation because of fewer air molecules, which is accounted for in Rayleigh scattering calculations by the pressure correction to relative air mass. Aerosol attenuation varies with the amount and type (size, composition) of aerosols; it generally increases with decreasing wavelength in the UV region.

Water vapor absorption (which is related to relative humidity and temperature) occurs outside of the UV region, so it affects the total broadband (280 to $4000 \mathrm{~nm}$ ) solar radiation values and therefore causes variability in the UV-to-broadband ratios. Relative humidity affects aerosol attenuation because hygroscopic particles take up water, grow larger, and increase the scattering by aerosol particles (e.g., haziness in high-humidity regions).

There are other gas absorption regions outside the UV region (e.g., oxygen absorption at $762 \mathrm{~nm}$ ), but their effects on solar radiation variations are small compared to effects of Rayleigh, aerosol, ozone, and water vapor.

The dominating attenuator of solar radiation is clouds. Under overcast skies there is no directbeam radiation, and under partly cloudy skies there is intermittent direct-beam solar radiation when clouds are not obscuring the sun's disk. Diffuse solar radiation is about $10 \%$ to $20 \%$ of the total amount of solar radiation under clear skies and $100 \%$ under overcast skies.

Clouds are often assumed to have a wavelength-independent attenuation function in the UV and visible region of the spectrum; but, in the near-infrared region they cause increased absorption due to water vapor and liquid water. There is some evidence that transmission is relatively higher in the UV and blue regions of the spectrum compared to a wavelength-independent function [4,5]. Increased ratios of UV-to-total solar radiation with increased cloud cover can be due to both decreased solar radiation in regions of the spectrum outside of the UV (caused by water vapor and liquid water absorption) and to relatively higher UV transmittance compared to wavelength-independent transmittance.

An index called $\mathrm{K}_{\mathrm{t}}$ is used in this report to describe total atmospheric transmittance due to all absorption and scattering processes

where

$$
\begin{aligned}
& \mathrm{K}_{\mathrm{t}}= \text { total global (direct }+ \text { diffuse) solar radiation on a horizontal surface divided by } \\
& \text { extraterrestrial solar radiation on a horizontal surface. }
\end{aligned}
$$

This is called a cloudiness or clearness index because it decreases with increasing atmospheric attenuation of solar radiation, which is mostly determined by cloudiness. 


\section{RATIOS OF UV-TO-TOTAL SOLAR RADIATION}

This section gives UV-to-total solar radiation ratios (converted to percent UV) reported in the literature, as well as measured values from SERI data. The relationships of these UV percentages to atmospheric conditions and air mass are also shown. Instrument descriptions and spectral response regions are described as they are reported in the various studies.

Elhadidy, et al. [6] analyzed measurements of UV solar radiation from January 1985 to December 1987 at Dhahran, Saudi Arabia $\left(26^{\circ} 32^{\prime} \mathrm{N}, 50^{\circ} 13^{\prime} \mathrm{E}\right)$. Total global solar radiation on a horizontal surface was measured with an Eppley Precision Spectral Pyranometer (PSP) and UV solar radiation on a horizontal surface was measured with an Eppley UV radiometer (photometer) having a response region from 295 to $385 \mathrm{~nm}$. The percentage of UV for monthly mean total radiation on a horizontal surface is given in Table 1.

Table 1. UV Percentage of Monthly Mean Total Global Solar Radiation on a Horizontal Surface at Dhahran, Saudi Arabia [6] .

\begin{tabular}{llll}
\hline MONTH & 1985 & 1986 & 1987 \\
\hline January & & & 3.39 \\
February & 3.50 & 3.39 & 3.57 \\
March & 3.34 & 3.50 & 3.48 \\
April & 3.42 & 3.55 & 3.45 \\
May & 3.50 & 3.65 & 3.39 \\
June & 3.47 & 3.49 & 3.22 \\
July & 3.39 & 3.47 & 3.31 \\
August & 3.29 & 3.35 & 3.40 \\
September & 3.45 & 3.43 & 3.33 \\
October & 3.44 & 3.43 & 3.41 \\
November & 3.46 & 3.42 & 3.45 \\
December & 3.54 & 3.46 & 3.40 \\
\multicolumn{1}{c}{ Mean } & 3.53 & 3.39 & \\
Overall Mean & & & \\
\hline
\end{tabular}

Results reported in this study were:

For days with a clearness index $\left(\mathrm{K}_{\mathrm{t}}\right)$ of more than 0.65 , the UV percentage of total solar radiation on a horizontal surface was approximately constant with about $95 \%$ of the values in the range of 3.3 to 3.8. The UV percentage was a very weak function of $K_{t}$ for days with $K_{t}$ greater than 0.65 . 
- $\quad$ For days with $\mathrm{K}_{\mathrm{t}}$ less than 0.65 , the UV percentage of total horizontal radiation depends on $\mathrm{K}_{\mathrm{t}}$ and on atmospheric conditions (for example, rain, clouds, and dust). The UV percentages were typically high for low $\mathrm{K}_{\mathrm{t}}(<0.50)$ but show more scatter than observed in the $\mathrm{K}_{\mathrm{t}}$ range of 0.50 to 0.65 . Examination of meteorological data revealed that the high UV percentages on days with $\mathrm{K}_{\mathrm{t}}$ less than 0.50 occurred on rainy or cloudy days while the low UV percentages occurred on dusty days.

- Comparison of clear- and cloudy-day data revealed higher UV percentages of total solar radiation on the cloudy days.

- The UV percentage of monthly-average-total solar radiation on a horizontal surface was nearly constant for the 3-year period (Table 1).

Al-Aruri, et al. [7] report results of UV measurements at the Kuwait Institute for Scientific Research $\left(29^{\circ} 20^{\prime} \mathrm{N}, 47^{\circ} 57^{\prime} \mathrm{E}\right)$ from July 1985 to June 1987 . Total global solar radiation on a horizontal surface was measured with a PSP, and UV solar radiation on a horizontal surface was measured with an Eppley UV radiometer (photometer) model TUVR with a response region from 295 to $385 \mathrm{~nm}$. Ratios of the monthly-mean-UV-to-monthly-mean-total solar radiation on a horizontal surface (in \%) are given in Table 2.

Table 2. UV Percentage of Monthly Mean Total Global Solar Radiation on a Horizontal Surface at the Kuwait Institute for Scientific Research [7]

\begin{tabular}{llll}
\hline MONTH & 1985 & 1986 & 1987 \\
\hline January & & 4.3 & 4.3 \\
February & & 4.4 & 4.4 \\
March & & 4.7 & 4.3 \\
April & 5.0 & 4.4 \\
May & 4.5 & 4.5 \\
June & & 4.4 & 4.2 \\
July & 4.6 & 4.6 & \\
August & 5.2 & 4.6 & \\
September & 5.1 & 4.6 & \\
October & 5.0 & 4.6 & \\
November & 5.1 & 4.9 & \\
December & 4.7 & 4.3 &
\end{tabular}

Results reported in this study were:

- On average, $4.62 \%$ of the monthly-daily total solar radiation received on a horizontal surface is UV.

- The daily total UV is approximately $44 \%$ lower on dusty days. 
Al-Aruri developed an empirical relationship between UV and total global horizontal solar radiation using a least-square linear regression of the monthly average daily measurements for the 3 years [8]. The relationship he derived between monthly average daily total global $(\mathrm{X})$ and $\mathrm{UV}$ solar radiation $(\mathrm{Y})$ is

$$
\mathrm{Y}=0.048 \mathrm{X}-0.014
$$

with a $\pm 3 \%$ standard error of the estimate and a coefficient of determination of $93 \%$. Similar regression analysis has been performed by Webb and Steven [9], Rao, et al. [10], and Stewart [11].

Rao, et al. [10] report UV and total global solar radiation measurements on a horizontal surface taken at Corvallis, Ore. $\left(44^{\circ} 34^{\prime} \mathrm{N}, 123^{\circ} 14^{\prime} \mathrm{W}\right.$, at $\left.65.5 \mathrm{~m}\right)$ for 3 years (1980 to 1982). An Eppley UV radiometer (photometer) Model TUVR (response region 295 to $385 \mathrm{~nm}$ ) was used to measure the UV radiation, and an Eppley PSP to measure the total. Mean daily values of the UV-to-total horizontal radiation ratios (in \%) are given in Table 3.

\section{Table 3. Mean Daily UV Percentage of Total Global Solar Radiation on a Horizontal Surface at Corvallis, Ore. [8]}

\begin{tabular}{|c|c|}
\hline Season & Mean \\
\hline Winter & 5.7 \\
\hline Spring & 5.3 \\
\hline Summer & 5.0 \\
\hline Fall & 5.6 \\
\hline
\end{tabular}

All $\quad 5.4$

For fractional sunshine values less than $15 \%$ (cloud amount $>6$ oktas), the percentage of UV was $6.3 \%$; between fractional sunshine values of $15 \%$ and $85 \%$ the percentage of UV was $5.1 \%$, and for fractional sunshine values greater than $85 \%$ (cloud amount $<2$ oktas) the percentage of UV was $4.6 \%$. The results of other measurements referenced by Rao, et al. are given in Table 4 .

Modeling results from Rao, et al. indicated that the UV solar radiation was relatively more sensitive to changes in atmospheric turbidity and surface albedo than to changes in the total amount of ozone in the atmosphere. The transition of the model atmosphere from "molecular" to "clear" resulted in decreases of up to 5\% in UV solar radiation as the solar zenith angle varied from $6.3^{\circ}$ to $77.6^{\circ}$; decreases were larger (5\% to $15 \%$ ) when the transition was from a "molecular" to "hazy" atmosphere over the same range of zenith angles. Changing the surface albedo from $0 \%$ to $25 \%$ resulted in UV enhancements of $8 \%$ to $10 \%$. In comparison, decreases of $2 \%$ to $4 \%$ in UV solar radiation were found for increases in ozone amount from $0.280 \mathrm{~atm}$ $\mathrm{cm}$ to $0.380 \mathrm{~atm} \mathrm{~cm}$. 
Table 4. UV Percentage of Total Global Solar Radiation on a Horizontal Surface (Computed Three Different Ways) Cited in Reference Number 10

\begin{tabular}{|c|c|c|}
\hline Reference & Measurement/Location & UV/Total \\
\hline Kvifte, et al. [12] & $\begin{array}{l}\text { Monthly mean ratios at various } \\
\text { subarctic locations (latitude } \\
\text { range } 55^{\circ} \mathrm{N} \text { to } 75^{\circ} \mathrm{N} \text { ) } \\
\text { in the Nordic countries }\end{array}$ & $4.4 \%-5.6 \%$ \\
\hline Schulze and Grafe [13] & $\begin{array}{l}\text { Monthly mean daily UV ( } 315- \\
400 \mathrm{~nm}) \text { at Hamburg }\left(53^{\circ}\right. \\
\left.33^{\prime} \mathrm{N}, 9^{\circ} 59^{\prime} \mathrm{E}\right)\end{array}$ & $5 \%-6 \%$ \\
\hline Baker-Blocker, et al. [14] & $\begin{array}{l}\text { Hourly average value of the } \\
\text { UV component under clear skies } \\
\text { during the austral summer of } \\
1979-1980 \text { at the Amundsen-Scott } \\
\text { station, Antarctica }\end{array}$ & $4 \%-5 \%$ \\
\hline
\end{tabular}

Measurements of UV and total global solar radiation, as well as other solar radiation and meteorological data, have been acquired at SERI's Solar Radiation Research Laboratory (SRRL), Golden, Colo. $\left(39^{\circ} 44^{\prime} \mathrm{N}, 105^{\circ} 10^{\prime} \mathrm{W}, 1828.8 \mathrm{~m}\right)$ for several years [15]. The data acquisition system records 5-min averages of 10-s scans of all channels. Total solar radiation measurements on a horizontal surface are made with an Eppley PSP, and UV measurements on a horizontal surface are made with an Eppley UV radiometer (photometer) model TUVR with a response region of 295 to $385 \mathrm{~nm}$. The measurement uncertainty for the PSP is less than $\pm 5 \%$, and the estimated measurement uncertainty for the TUVR is $\pm 15 \%$; thus, the uncertainty in the ratio of these two measurements is on the order of $\pm 20 \%$. Figure 4 shows the ratio of 5-min UV-to-total horizontal measurements (in \%) versus $\mathrm{K}_{\mathrm{t}}$ for 1989 at SRRL. These data show an average UV percentage of about $4.5 \%$ to $5 \%$ for clear skies $\left(\mathrm{K}_{\mathfrak{t}}>0.60\right)$, with a general increase in the percentage of UV (with much scatter) with decreasing $\mathrm{K}_{\mathrm{t}}$ as observed by others referenced here.

Direct-normal spectral UV solar radiation measurements have been made at SERI to obtain wavelength-specific information needed for the Solar Thermal Technology Program's evaluation of processes that use concentrated direct-normal solar radiation and catalysts operating a specific wavelengths to detoxify hazardous wastes. Several of these spectral measurements are shown in Figure 5 together with the estimated spectral measurement uncertainty (bottom of the figure). Rather than a total UV measurement on a horizontal surface, the measured spectra in Figure 5 are for a $5.7^{\circ}$ field of view looking directly at the sun's disk (direct-normal). The spectra were acquired with an ISA/DH10 spectroradiometer (Table 5). The broadband direct-normal data were acquired with an Eppley normal-incidence pyrheliometer (NIP), also with a $5.7^{\circ}$ field of view, with a measurement uncertainty of less than $\pm 2 \%$. 


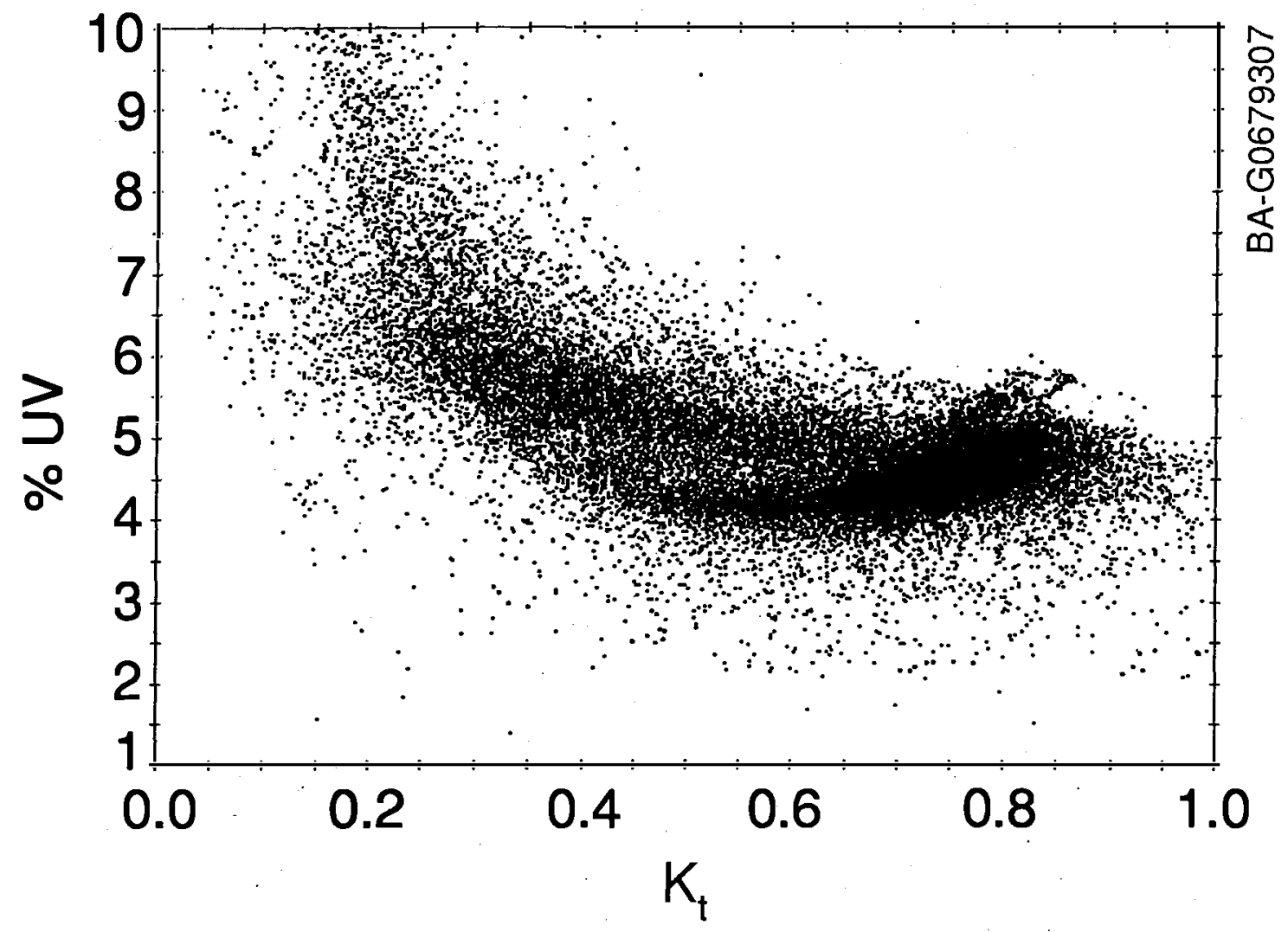

Figure 4. Ratio of 5-minute values of UV global horizontal to total global horizontal solar radiation versus $K_{\mathfrak{l}}$ (measured at the SERI Solar Radiation Research Laboratory, January through December 1989)

The results of integrating the direct-normal spectra from 280 to $385 \mathrm{~nm}$ and from 280 to $400 \mathrm{~nm}$, and dividing by the broadband direct-normal (NIP) measurement are shown in Table 6. Because the measurement uncertainty in the spectra beyond about $310 \mathrm{~nm}$ is on the order of $10 \%$ to $20 \%$, the uncertainty in the ratios of integrated spectra to NIP values is on the order of $10 \%$ to $20 \%$.

The direct-normal UV measurements decrease rapidly with increasing air mass because of increased Rayleigh and aerosol scattering with longer path lengths through the atmosphere. The shorter (UV) wavelengths are scattered more than the longer wavelengths as shown by the wavelength-dependent Rayleigh and aerosol transmission functions given in Section 2. Totalhorizontal (direct + diffuse) UV solar radiation is reduced to a lesser extent because some of the radiation that is scattered out of the direct beam is scattered toward the earth's surface and received as diffuse irradiance by a flat surface. 


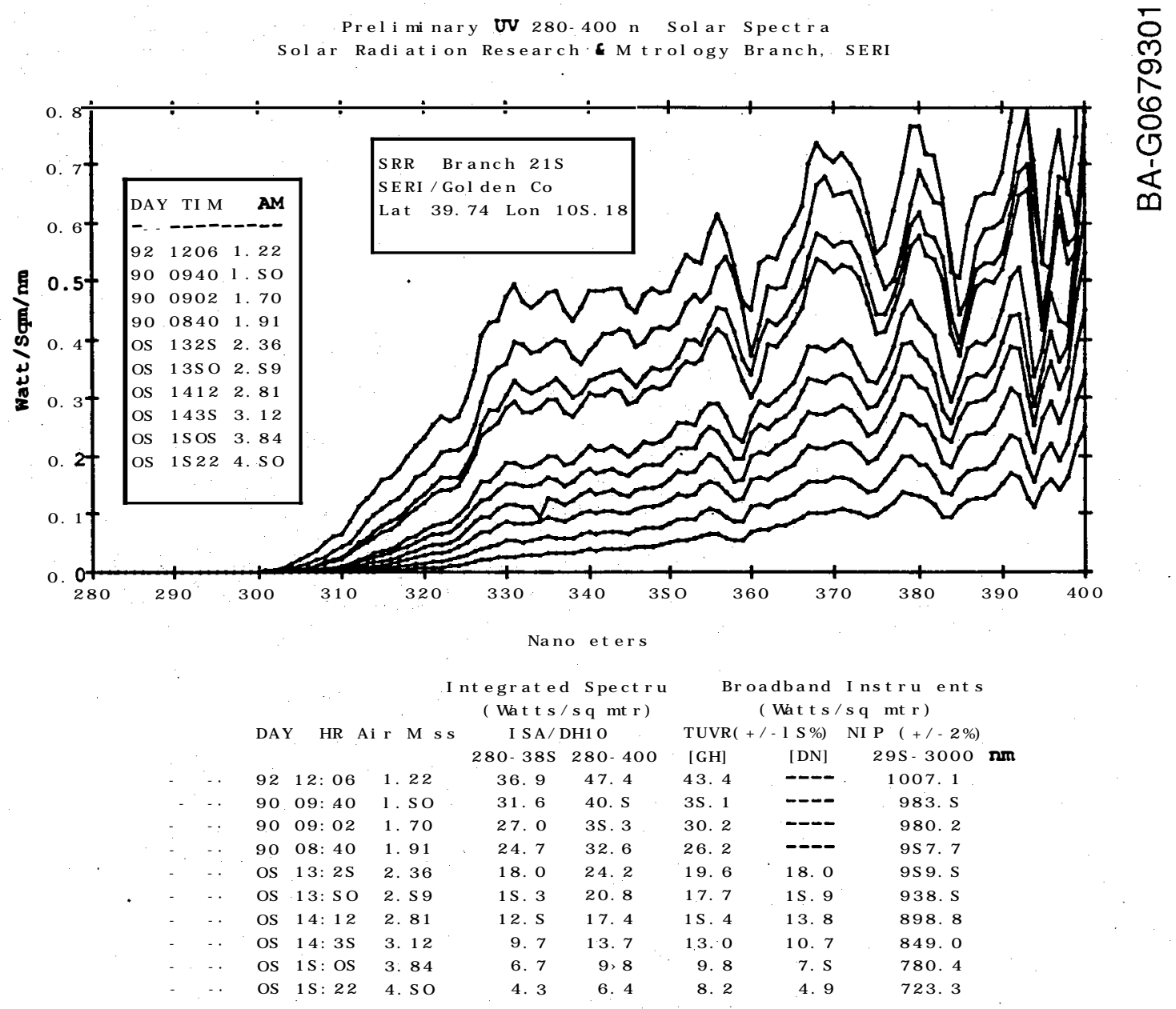

STATED M ASUREM NT U CERTAINTY I NCLUDES ALLOWA CES FOR THE A PA ENT

1. 0 TO 1.S NM SHIFT BET EEN M ASURE NT SETS 3S0-400 NM

ESTI M TED ISA/ DH1O Uncertainty

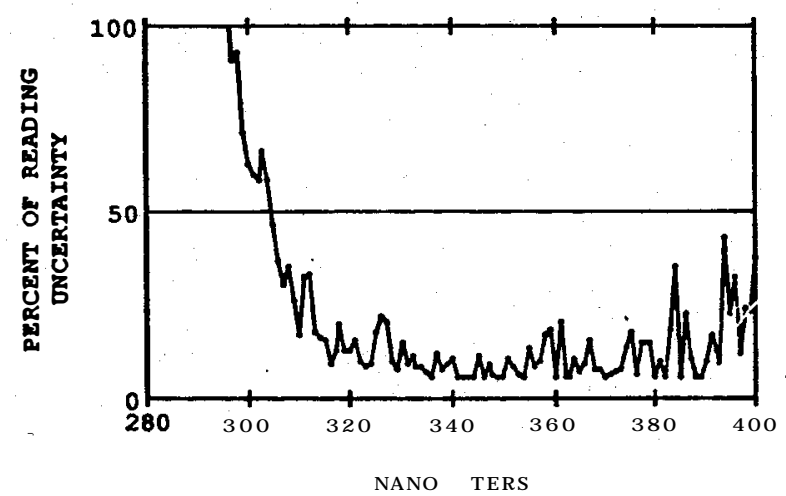

SR 1 I Wave Bias-(CA Meas.)

SR O.S $n$ Wave Ran-(CAL \& Meas.)

CAI Sources: Ar ARC, FEL (NIST)

CAL Current Monitor (DM S)

CAI Current Shunt

CA Dist ance

CAI Ai $r$ Pressure

CAI Power Suppl Y

CAL Argon Purity

CA Argon Flow Rate

CAL Arc Align ent

SR PM Volt age (Ti e, Te p.)

$S R$ Integ. Ti e Li nearity (Tem.)

SR Stray Light

SR A/D conversion

Figure 5. Instantaneous direct-normal UV spectral solar radiation measurements and supporting data acquired at SERI in January and April 1990 (upper graph); spectral measurement uncertainty (lower graph) where CAL indicates calibration error sources and SR indicates spectroradiometer error sources 
Table 5. Some Characteristics of the ISA/DH10 Spectroradiometer

Spectral range

Passband

Linear dispersion

Wavelength accuracy

Calibration
200 to $800 \mathrm{~nm}$

$2 \mathrm{~nm}$

$4 \mathrm{~nm}$ per $\mathrm{nm}$

$\pm 1 \mathrm{~nm}$

a) National Institute of Standards and Technology (NIST) Argon Arc from 250 to $330 \mathrm{~nm}$

b) NIST 1000-watt type FEL incandescent lamp from 330 to $500 \mathrm{~nm}$

Table 6. UV Percentage of Total Direct Normal Solar Radiation for Instantaneous Measurements at Golden, Colo.

\begin{tabular}{llcc}
\hline $\begin{array}{l}\text { Air } \\
\text { Mass }\end{array}$ & $\begin{array}{l}\text { Pressure } \\
\text { Corrected } \\
\text { Air Mass }\end{array}$ & $\begin{array}{c}280-385 \mathrm{~nm} \\
-------\end{array}$ & $\begin{array}{l}280-400 \mathrm{~nm} \\
\text { NIP }\end{array}$ \\
\hline 1.22 & 1.01 & $3.7 \%$ & NIP \\
1.50 & 1.24 & $3.2 \%$ & $4.7 \%$ \\
1.70 & 1.41 & $2.8 \%$ & $3.6 \%$ \\
1.91 & 1.58 & $2.6 \%$ & $3.4 \%$ \\
2.36 & 1.96 & $1.9 \%$ & $2.5 \%$ \\
2.59 & 2.15 & $1.6 \%$ & $2.2 \%$ \\
2.81 & 2.33 & $1.4 \%$ & $1.9 \%$ \\
3.12 & 2.59 & $1.1 \%$ & $1.6 \%$ \\
3.84 & 3.18 & $0.9 \%$ & $1.3 \%$ \\
4.50 & 3.73 & $0.6 \%$ & $0.9 \%$ \\
\hline
\end{tabular}

Other spectral measurements are available from SERI's spectral solar radiation data base produced under the DOE/SERI Resource Assessment Program [16-18]. This data base contains about 3000 measured spectra covering the spectral region from 300 to $1100 \mathrm{~nm}$ at $2-\mathrm{nm}$ steps. Broadband solar radiation and meteorological data were recorded at the same time as the spectra. Measurements were acquired at the Florida Solar Energy Center, Cape Canaveral, Fla.; the Pacific Gas and Electric Co., San Ramon, Calif.; and by SERI in Denver and Golden, Colo. Several different measurement modes were used to acquire the spectra, including direct normal and global on a horizontal surface. The spectroradiometer used to acquire these data was not designed specifically for UV measurements, and the measurement uncertainty of the data in the region from 300 to $400 \mathrm{~nm}$ is high ( $> \pm 20 \%$ ); however, these data can be used to examine the variability in the UV-to-total ratios with respect to air mass and $\mathrm{K}_{\mathbf{t}}$. 
Figure 6 shows the total (direct + diffuse) integrated global-horizontal spectral solar radiation from 300 to $400 \mathrm{~nm}$ divided by total global-horizontal solar radiation measured with an Eppley PSP (in \%) as a function of $K_{t}$. These data show an increasing UV percentage for cloudy skies as indicated by others referenced here. The mean UV percentage for clear skies $\left(K_{t}>0.60\right)$ is $6.1 \%$, the mean percentage for cloudy skies $\left(\mathrm{K}_{\mathrm{t}}<0.40\right)$ is $8.6 \%$, and the overall mean is $6.3 \%$. The Denver site, which is at a higher elevation (about $1555 \mathrm{~m}$ ) and is drier than the California and Florida sites, shows a lower percentage of UV (about 5\% versus 6.3\%), although the differences could be due to measurement uncertainty.

Figure 7 shows the integrated direct-normal spectral solar radiation from 300 to $400 \mathrm{~nm}$ measured by the LI-COR spectroradiometer divided by the total direct-normal solar radiation measured with a NIP (in \%), as a function of air mass (air mass is pressure-corrected for the Denver measurements included in the data set). Also shown are the UV percentages of total direct normal solar radiation measured by the ISA spectroradiometer (from Table 6). Quadratic fits to

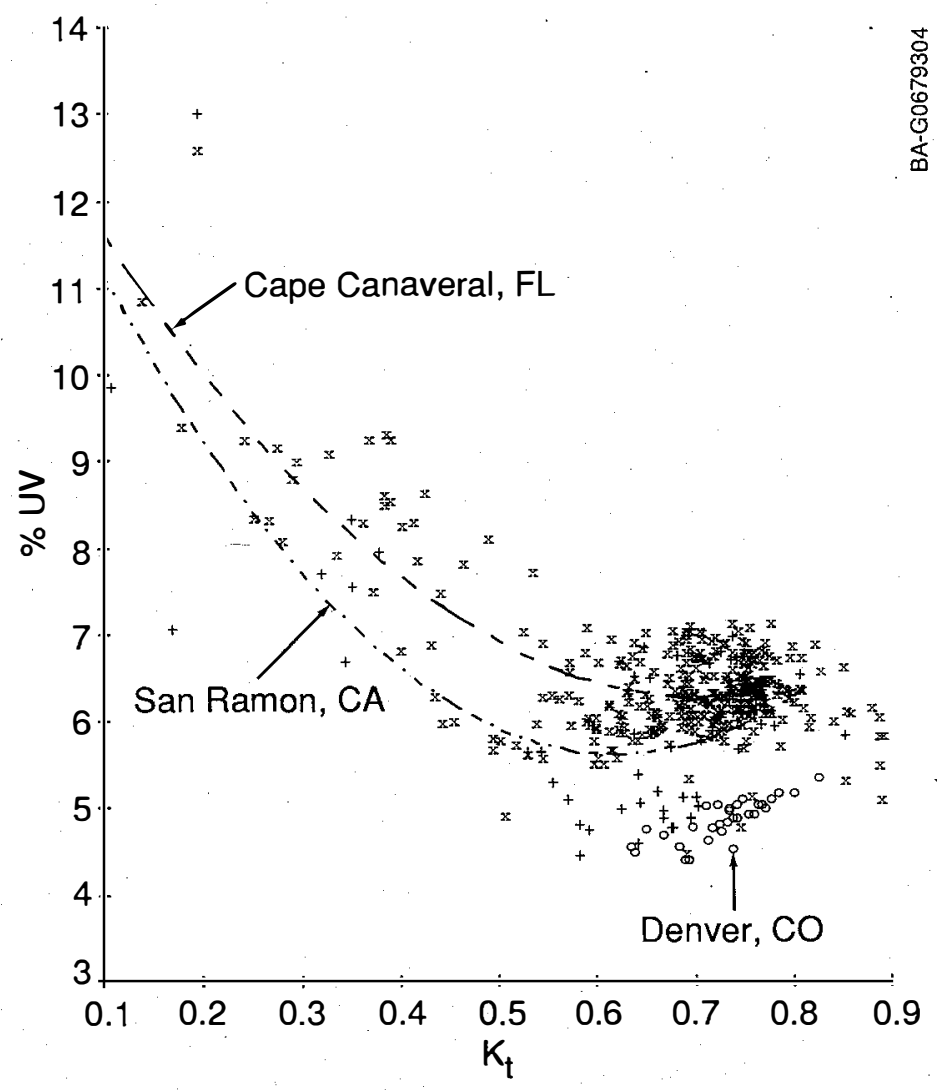

Figure 6. Ratio of integrated UV $(300-400 \mathrm{~nm})$ global horizontal solar radiation (measured with a LI-COR model LI-1800 spectroradiometer at 2-nm steps) to total global horizontal solar radiation measured with a PSP versus $K_{t}$ 
these data show the relative percentage of UV solar radiation in three slightly different UV wavelength regions. These data show the air mass dependence of direct-normal UV solar radiation with mean values of about $4 \%$ at low air mass values to about $0.5 \%$ to $1 \%$ at high air mass values. The scatter in the UV percentages calculated from the LI-COR data is due to measurement uncertainty and differences in atmospheric conditions (aerosols, water vapor, etc.) at the time of these instantaneous measurements.

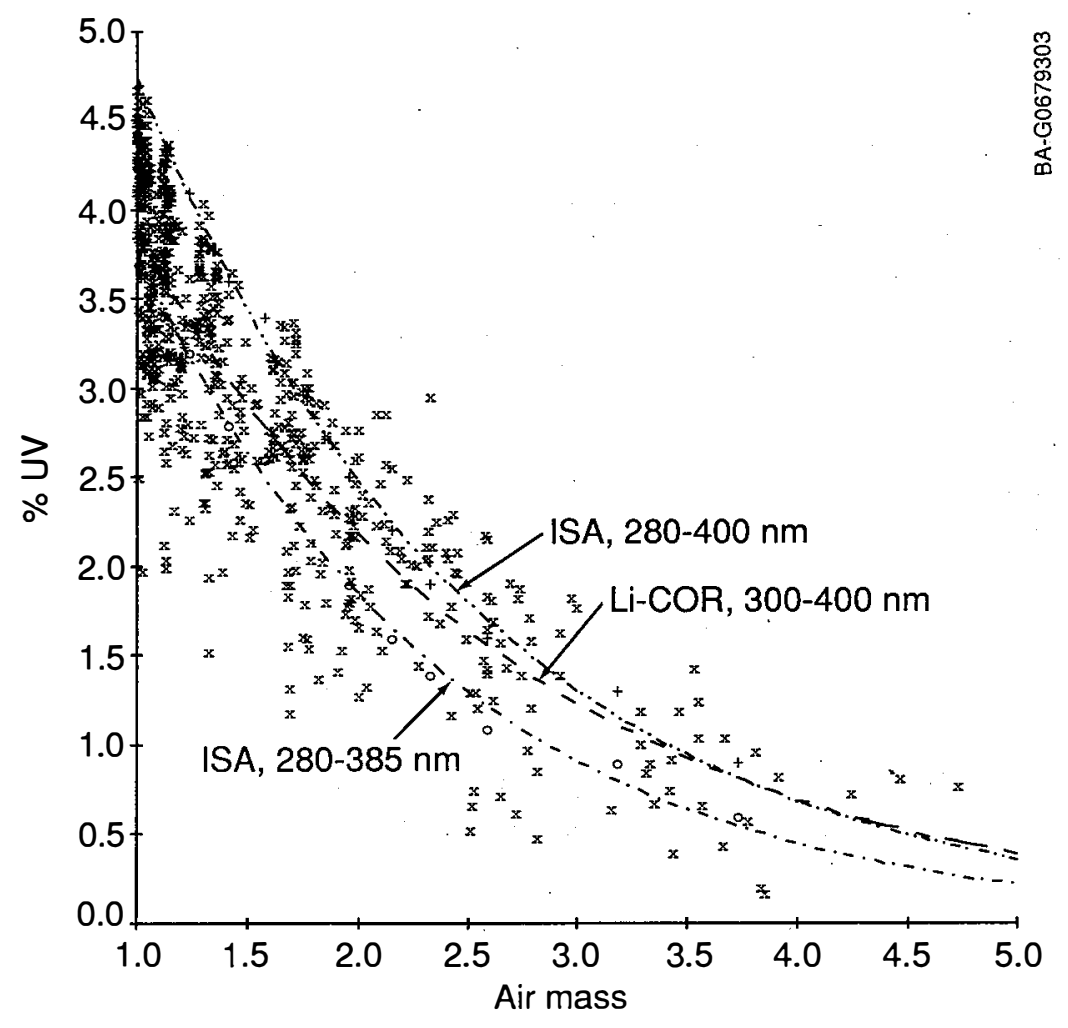

Figure 7. Ratio of integrated UV $(300-400 \mathrm{~nm})$ direct-normal solar radiation to total direct-normal solar radiation measured with an NIP. The top and bottom curves are quadratic curve fits to the ratios based on data measured with the ISA UV spectroradiometer integrated between 280 and $400 \mathrm{~nm}$ (top) and between 280 and $385 \mathrm{~nm}$ (bottom). The middle curve is a quadratic curve fit to data measured with a LI-COR model LI-1800 spectroradiometer and integrated between 300 and $400 \mathrm{~nm}$. 


\section{SUMMARY AND CONCLUSIONS}

The major atmospheric variables that determine the UV percentage of total solar radiation are molecular (Rayleigh) scattering, aerosol absorption and scattering, ozone absorption, water vapor absorption, and scattering and absorption by clouds. A general index of atmospheric transmittance due to all of these processes is $K_{t}$, which is mostly determined by cloudiness. However, the spectral selectivity of the different atmospheric attenuators causes the ratio of UVto-total solar radiation at a specific $\mathrm{K}_{\mathrm{t}}$ to vary. In addition, ratios of UV-to-total direct normal solar radiation are a strong function of air mass because of the strong wavelength and air mass dependence of Rayleigh scattering. Also, there is no direct-beam solar radiation when clouds obscure the sun's disk.

UV measurements reported in the literature and acquired by SERI show the following relationships to $\mathrm{K}_{\mathrm{t}}$ and air mass.

- The UV percentage of total global (direct + diffuse) solar radiation on a horizontal surface generally increases with decreasing $K_{t}$ (i.e., lower atmospheric transmittance mostly due to clouds, but also to aerosols or dust); but, the amount of scatter in the ratio increases with lower $\mathrm{K}_{\mathrm{t}} \mathrm{s}$.

- Mean monthly values for the UV percentage of total global horizontal solar radiation generally range from about $3.5 \%$ to $8 \%$ for the sites reported here. The UV percentages for Dhahran, Saudi Arabia, are noticeably lower than percentages reported for the other sites but the differences could be within the measurement uncertainty. Mean values for the percentage of UV for cloudy skies are about 2 percentage points higher than mean clear-sky percentages [for example, $4.6 \%$ (clear) versus $6.3 \%$ (cloudy) or $6.1 \%$ (clear) versus $8.6 \%$ (cloudy)]. As expected, the scatter in the values increases for instantaneous versus monthly mean values.

- The mean value of the UV percentage of total direct normal solar radiation decreases with air mass. SERI measurements show mean percentages of about $4 \%$ to $5 \%$ for air masses near 1.0, decreasing to about $0.5 \%$ for air masses near 4 for cloudless sky conditions. Under overcast skies there is no direct beam, and under partly cloudy skies there is intermittent direct-beam when the clouds are not obscuring the sun's disk.

Preliminary estimates of average monthly global UV solar radiation on a horizontal surface for various locations could be based on total global solar radiation and the mean ratios of UV-toglobal solar radiation as a function of $\mathrm{K}_{\mathrm{t}}$. Estimates of direct-normal solar radiation for various locations could be based on total direct-normal solar radiation and the mean ratio of UV-to-direct normal solar radiation as a function of air mass, where air mass is a function of the latitude, time of day, and day of the year. The shortcomings of these methods are that the mean ratios have been shown to vary with location due to measurement uncertainty and different atmospheric conditions (for example, water vapor absorption outside of the UV region affects the ratio of UVto-total ratio; and, water vapor varies by site, time of day, and season), and there is no spectral detail. If the absolute amounts and spectral distributions of UV solar radiation are critical to analyze processes that depend on UV solar radiation (atmospheric chemistry, biological processes, 
or solar detoxification of hazardous wastes), more accurate and precise measurements and measurement uncertainty analysis are required.

In the specific case of UV solar radiation resource assessment in the United States for the Solar Thermal Technology Program's solar detoxification of hazardous wastes, the following actions are recommended to obtain a preliminary estimate of UV solar radiation resources.

- Total global horizontal UV solar radiation resource assessment (flat, horizontal surface processes).

Obtain SOLMET (SOLar METeorological) data from the U.S. National Climatic Data Center for selected sites in the United States, extract hourly global-horizontal solar radiation values, calculate $K_{t}$, and multiply the global-horizontal values by an average percentage of $\mathrm{UV}$ as a function of $\mathrm{K}_{\mathrm{t}}$. Both conservative and optimistic estimates can be made. Based on the data reported here, a conservative estimate might be based on UV percentages of $4 \%$ (clear) to $6 \%$ (cloudy), and an optimistic estimate might be based on UV percentages of $6 \%$ (clear) to $8 \%$ (cloudy).

- Direct-normal UV solar radiation resource assessment (concentrator collector processes).

Obtain SOLMET data for selected sites in the United States, extract hourly globalhorizontal solar radiation values, calculate direct-normal solar radiation from the globalhorizontal values using the DISC model [19] (an improved model for deriving directnormal from global-horizontal solar radiation), calculate hourly air mass values, and multiply the modeled direct-normal values by an average percentage of UV as a function of air mass derived from Figure 7. Conservative and optimistic estimates of UV resources can be made using high and low percentages from Figure 7.

- Obtain global-horizontal, direct-normal, and UV data for sites with actual measurements.

- Perform a sensitivity analysis to determine if the UV resource uncertainty is a critical factor in the viability of the solar detoxification technology, which will necessitate more precise measurements and resource assessments for the technology evaluation.

Both Sandia National Laboratories, Albuquerque, N. Mex., and SERI, Golden, are taking directnormal UV and broadband measurements that will be used to develop UV data bases for their two sites. 


\section{REFERENCES}

1. Wehrli, C., "Extraterrestrial Solar Spectrum," Pub. No. 615, Davos, Switzerland: World Radiation Center, 1985.

2. Kasten, F. and A.T. Young, "Revised Optical Air Mass Tables and Approximation $\ddot{Y}$ Formula," Applied Optics, Vol. 28, No. 22, 1989, pp. 4735-4738. Ÿ

3. Iqbal, M., An Introduction to Solar Radiation, New York: Academic Press, 1983.

4. Nann, S. and C. Riordan, "Solar Spectral Irradiance Under Overcast Skies," 21st IEEE Ÿ Photovoltaic Specialists Conference, Orlando, FL, May 1990. Ÿ

5. Nann, S. and C. Riordan, "Solar Spectral Irradiance Measurements and Model for All-Sky Ÿ Conditions," submitted to Journal of Applied Meteorology, June 1990. Ÿ

6. Elhadidy, M.A., D.Y. Abdel-Nabi, and P.D. Kruss, "Ultraviolet Solar Radiation at $\ddot{Y}$ Dhahran, Saudi Arabia," Solar Energy, Vol. 44, No. 6, 1990, pp. 315-319. Ÿ

7. Al-Aruri, S., M. Rasas, K. Al-Jamal, and N. Shaban, "An Assessment of Global Ultraviolet Solar Radiation in the Range $(0.290-0.385 \mu \mathrm{m})$ in Kuwait," Solar Energy, Vol. 41, No. 2, 1988, pp. 159-162.

8. Al-Aruri, S.D., "The Empirical Relationship Between Global Radiation and Global Ultraviolet (0.290-0.385 $\mu \mathrm{m})$ Solar Radiation Components," Solar Energy, Vol. 45, No. 2, 1990, pp. 61-64.

9. Webb, A.R. and M.D. Steven, "Daily Totals of Solar UVB Radiation Estimated From Routine Meteorological Measurements," Journal of Climatology, Vol. 6, 1986, pp. 405-411.

10. Rao, C.R.N., T. Takashima, W.A. Bradley, and T.Y. Lee, "Near Ultraviolet Radiation at the Earth's Surface: Measurements and Model Comparisons," Tellus, 36B, 1984, pp. 286293.

11. Stewart, R., Solar Energy Meteorological Research and Training Site Program, Second Annual Report, SERI-SP-290-1478, Golden, CO: Solar Energy Research Institute, 1980, pp. 28-31.

12. Kvifte, G., K. Hegg, and V. Hansen, "Spectral Distribution of Solar Radiation in Nordic Countries," J. Climate Appl. Meteorol., 22, 1983, pp. 143-152.

13. Schulze, R. and K. Grafe, "Consideration of Sky Ultraviolet Radiation in the Measurement of Solar Ultraviolet Radiation," in: The Biologic Effects of Ultraviolet Radiation (ed. F. Urbach), New York: Pergamon Press, 1969, pp. 359-373. 
14. Baker-Blocker, A., J.J. DeLuisi, and E. Dutton, "Calculated and Observed Values of Ultraviolet Radiation During A South Pole Summer," EOS Trans. Am. Geophys. Union, 63, 1982, pp. 896-897.

15. Riordan, C., R. Hulstrom, E. Maxwell, T. Stoffel, M. Rymes, D. Myers, and S. Wilcox, "SERI Solar Radiation Resource Assessment Project: FY 1989 Annual Progress Report," SERI/PR-215-3617, Golden, CO: Solar Energy Research Institute, 1990.

16. Riordan, C., D. Myers, M. Rymes, R. Hulstrom, W. Marion, C. Jennings, and C. Whitaker, "Spectral Solar Radiation Data Base at SERI," Solar Energy, Vol. 42, No. 1, 1989, pp. 67-79.

17. Myers, D.R., "Estimates of Uncertainty for Measured Spectra in the SERI Spectral Solar Radiation Data Base," Solar Energy, Vol. 43, No. 6, 1989, pp. 347-353.

18. Riordan, C., D.R. Myers, and R.L. Hulstrom, "Spectral Solar Radiation Data Base Documentation," Volumes I and II, SERI/TR-215-3513A and B, Golden, CO: Solar Energy Research Institute, 1990.

19. Maxwell, E., "Direct Insolation Code-DISC," Golden, CO: Solar Energy Research Institute, (personal contact for computer code).

\section{Additional References}

Anon., "UV Exposure Implicated in Skin Cancer, Eye Disease," The Changing Atmosphere, Chemical \& Engineering News, Vol. 64, No. 47, November 24, 1986, p. 32.

Baker-Blocker, A., J.J. DeLuisi, and E. Dutton, "Received Ultraviolet Radiation at the South Pole," Solar Energy, Vol. 32, No. 5, 1984, pp. 659-662.

Barker, R.E., Jr., "The Availability of Solar Radiation Below $290 \mathrm{~nm}$ and its Importance in Photomodification of Polymers," Photochemistry and Photobiology, Vol. 7, 1968, pp. 275-295.

Bird, R.E. and R.L. Hulstrom, "Extensive Modeled Terrestrial Solar Spectral Data Sets with Solar Cell Analysis," SERI/TR-215-1598, Golden, CO: Solar Energy Research Institute, 1982.

Bird, R.E., R.L. Hulstrom, A.W. Kliman, and H.G. Eldering, "Solar Spectral Measurements in the Terrestrial Environment", Applied Optics, Vol. 21, No. 8, 1982, pp. 1430-1436.

Bittar, A. and R.L. McKenzie, "Spectral UV Intensity Measurements at $45^{\circ}$ S.," J. Geophys. Res., Vol. 95, No. D5, 1990, pp. 5597-5603.

Bjorn, L.O. and T.M. Murphy, "Computer Calculation of Solar Ultraviolet Radiation at Ground Level," Physiol. Veg., 23, 1985, pp. 555-561. 
Collins, B.G., "Ultraviolet Radiation at Aspendale, Australia," Aust..Meteorol. sviay., 21, 1973, pp. 113-118.

Correll, D.L., C. Clark, R. Goodrich, and D. Hayes, "UVB Monitoring Data from Mauna Loa and Rockville," Geophysical Monitoring for Climatic Change, No. 17, Summary'Report 1988, Boulder, CO: National Oceanic and Atmospheric Administration, Air Resources Laboratory, December 1989, pp. 87-88.

Frederick, J.E. and H.E. Snell, "Ultraviolet Radiation Levels During the Antarctic Spring," Science, Vol. 241, 1988, pp. 438-440.

Frederick, J.E. and D. Lubin, "The Budget of Biologically Active Ultraviolet Radiation in the Earth-Atmosphere System," J. of Geophysical Research, Vol. 43, No. D4, 1988, pp. 3825-3832.

Green, A.E.S., "The Penetration of Ultraviolet Radiation to the Ground," Physiol. Plant, 58, Copenhagen, 1989, pp. 351-359.

Green, A.E.S., K.R. Cross, and L.A. Smith, "Improved Analytic Characterization of Ultraviolet Skylight," Photochemistry and Photobiology, Vol. 31, 1980, pp. 59-65.

Green, A.E.S., J.C. Wagner, and A. Mann, "Analytic Spectral Functions for Atmospheric Transmittance Calculations," Applied Optics, Vol. 27, 1988, pp. 2266-2272.

Green, A.E.S., T. Sawada, and E.P. Shettle, "The Middle Ultraviolet Reaching the Ground," Photochemistry and Photobiology, Vol. 19, 1974, pp. 251-259.

Green, A.E.S. and Shun-Tie Chai, "Solar Spectral Irradiance in the Visible and Infrared Regions," Photochemistry and Photobiology, Vol. 48, No. 44, pp. 477-486.

Hulstrom, R.L., "A Preliminary Estimate of Spectral UV Direct-Beam Solar Irradiance at the Earth's Surface," Provided as guidance to the SERI Solar Thermal Technology Program, No. 25, 1987, (internal only).

Hulstrom, R.L., R.E. Bird, and C. Riordan, "Spectral Solar Irradiance Data Sets for Selected Terrestrial Conditions," Solar Cells, Vol. 15, 1985, pp. 365-391.

Klein, W.H. and B. Goldberg, Smithsonian Radiation Biology Laboratory, "Solar Radiation Measurements, Series 1968-1973, 1974-1975, 1976-1977, 1978-1979." (Total irradiance data UV $<420 \mathrm{~nm}$ for Rockville, MD; Panama Canal Zone; Barrow, AK. Daily average plots by month, plus tables of data $295-2800 \mathrm{~nm}$ ).

Lowe, R.P., et al., "A Survey of Solar-Blind Ultraviolet Technology," Department of Physics, University of Western Ontario, London, Ontario, Canada, March 1980, 343 p. plus references (microfilm - ELM). 
McKenzie, R.L., "UV.Irradiance Calculations and Their Application to New Zealand," submitted to Photochemistry and Photobiology (1989).

McKenzie, R.L. and J.M. Elmwood, "Intensity of Solar Ultraviolet Radiation and Its Implications for Skin Cancer," The New England Medical Journal, Vol. 103, No. 887, April 1990, pp. 152-154.

Mims III, F.M., "The Amateur Scientist, How to Monitor Ultraviolet Radiation from the Sun," Scientific American, August 1990, pp. 106-109.

Nichol, S.E. and R.E. Basher, "Analysis of Three Years' Measurements of Erythemal Ultraviolet Radiation at Invercargill, New Zealand," New Zealand Meterorological Service, Scientific Report 21, 1986, (referenced by Elhadidy).

Patterson, E.M. and J.B. Gillespie, "Simplified Ultraviolet and Visible Wavelength Atmospheric Propagation Model," Applied Optics, Vol. 28, No. 3, 1989, pp. 425-429.

Rao, C.R.N. and T. Takashima, "Measured and Computed Values of Clear-Sky Ultraviolet Irradiance at the South Pole," Solar Energy, Vol. 34, No. 4/5, 1985, pp. 435-437.

Schaefer, B:E., "The Astrophysics of Suntanning," Sky \& Telescope, 1988, pp. 595-596.

Scotto, J., G. Cotton, F. Urbach, D. Berger, and T. Fears, "Biologically Effective Ultraviolet Radiation: Surface Measurements in the United States, 1974 to 1985," Science, Vol. 239, 1988, pp. 762-764.

Slusser, J., R. Kinmonth, and R. Leber, "The Atlas Model LM3A: A Narrow Band Filter Radiometer for Monitoring Solar Ultraviolet Irradiance and Radiant Exposure," Atlas Sunspot, Vol. 18, No. 39, Winter 1988.

UV - Extraterrestrial References:

Anderson, G.P. and L.A. Hall, "Solar Irradiance Between 2000 and 3100 Angstroms with Spectral Band Pass of 1.0 Angstroms," Journal of Geophysical Research, Vol. 94, No. D5, May 20, 1989, pp. 6435-6441.

Labs, D.H., P.C. Simon, and G. Thuillier, "Ultraviolet Solar Irradiance Measurement from 200 to $358 \mathrm{~nm}$ During SPACELAB 1 Mission," Solar Physics, 107, 1987, pp. 203-219. 


\begin{tabular}{|c|c|c|c|}
\hline $\begin{array}{c}\text { Document Control } \\
\text { Page }\end{array}$ & $\begin{array}{l}\text { 1. SERI Report No. } \\
\text { SERI/TP-215-3895 }\end{array}$ & $\begin{array}{l}\text { 2. NTIS Accession No. } \\
\text { DE90000368 }\end{array}$ & 3. Recipient's Accession No. \\
\hline \multirow{2}{*}{\multicolumn{3}{|c|}{$\begin{array}{l}\text { 4. Title and Subtitle } \\
\text { Influences of Atmospheric Conditions and Air Mass on the Ratio of } \\
\text { Ultraviolet to Total Solar Radiation }\end{array}$}} & $\begin{array}{l}\text { 5. Publication Date } \\
\text { August } 1990\end{array}$ \\
\hline & & & 6. \\
\hline $\begin{array}{l}\text { 7. Author(s) } \\
\text { C. J. Riordan, R. I }\end{array}$ & ulstrom, D. R. Myers & & 8. Performing Organization Rept. No. \\
\hline \multirow{2}{*}{\multicolumn{3}{|c|}{$\begin{array}{l}\text { 9. Performing Organization Name and Address } \\
\text { Solar Energy Research Institute } \\
\text { 1617 Cole Boulevard } \\
\text { Golden, Colorado } 80401-3393\end{array}$}} & 10. Project/Task/Work Unit No. \\
\hline & & & $\begin{array}{l}\text { 11. Contract (C) or Grant (G) No. } \\
\text { (C) } \\
\text { (G) }\end{array}$ \\
\hline \multirow{2}{*}{\multicolumn{3}{|c|}{ 12. Sponsoring Organization Name and Address }} & $\begin{array}{l}\text { 13. Type of Report \& Period Covered } \\
\text { Technical Report }\end{array}$ \\
\hline & & & 14. \\
\hline \multicolumn{4}{|c|}{ 15. Supplementary Notes } \\
\hline \multicolumn{4}{|c|}{$\begin{array}{l}\text { 16. Abstract (Limit: } 200 \text { words) } \\
\text { This report describes the major atmospheric variables that determine the amount of UV solar radiation at the } \\
\text { earth's surface, and how the ratio of UV-to-total solar radiation varies with atmospheric conditions. These ratios } \\
\text { are calculated from broadband and spectral solar radiation measurements acquired at SERI, and obtained from the } \\
\text { literature on modeled and measured UV solar radiation. The report also discusses the atmospheric effects on UV } \\
\text { solar radiation, and provides UV-to-total solar radiation ratios from published studies, as well as measured values } \\
\text { from SERI's data. }\end{array}$} \\
\hline \multicolumn{4}{|c|}{$\begin{array}{l}\text { 17. Document Analysis } \\
\text { a. Descriptors } \\
\text { Detoxification of hazardous wastes ; reso } \\
\text { solar radiation ratios } \\
\text { b. Identifiers/Open-Ended Terms }\end{array}$} \\
\hline \multicolumn{4}{|l|}{$\begin{array}{l}\text { c. UC Categories } \\
233,234\end{array}$} \\
\hline \multirow{2}{*}{\multicolumn{2}{|c|}{$\begin{array}{l}\text { 18. Availability Statement } \\
\text { National Technical Information Service } \\
\text { U.S. Department of Commerce } \\
5285 \text { Port Royal Road } \\
\text { Springfield, VA } 22161\end{array}$}} & & $\begin{array}{l}\text { 19. No. of Pages } \\
28 \\
\end{array}$ \\
\hline & & & $\begin{array}{l}\text { 20. Price } \\
\text { A03 }\end{array}$ \\
\hline
\end{tabular}

Form No. 0069E (6-30-87) 